\title{
IDENTIFIKASI AIRTANAH ASIN BERDASARKAN PENDUGAAN GEOLISTRIK DI PESISIR KOTA CILACAP JAWA TENGAH
}

\author{
Oleh: \\ Setyawan Purnama ${ }^{1}$, Ahmad Cahyadi ${ }^{1,2}$, Erik Febriarta ${ }^{2}$, Nurul Khakhim ${ }^{3}$, \\ dan Hari Prihatno ${ }^{4}$ \\ ${ }^{1}$ Jurusan Geografi Lingkungan, Fakultas Geografi, Universitas Gadjah Mada Yogyakarta \\ ${ }^{2}$ Magister Perencanaan Pengelolaan Pesisir dan Daerah Aliran Sungai (MPPDAS) \\ Fakultas Geografi Universitas Gadjah Mada Yogyakarta \\ ${ }^{3}$ Pusat Sumberdaya dan Teknologi Kelautan Universitas Gadjah Mada Yogyakarta \\ ${ }^{4}$ Pusat Penelitian Pengembangan Sumberdaya Laut dan Pesisir (P3SDLP) \\ Kementerian Kelautan dan Perikanan Republik Indonesia \\ Email: ${ }^{1}$ SetyaPurna@geo.ugm.ac.id
}

\begin{abstract}
Abstrak
Airtanah merupakan salah satu sumberdaya air potensial yang dapat digunakan untuk memenuhi kebutuhan air manusia. Pemanfaatan airtanah yang berlebihan di wilayah pesisir seringkali menyebabkan terjadinya intrusi air laut. Penelitian ini bertujuan untuk mengetahui keterdapatan airtanah asin di Pesisir Kota Cilacap. Analisis dilakukan dengan pendugaan geolistrik. Analisis data dilakukan dengan menggunakan software IP2Win. Hasil analisis menunjukkan bahwa airtanah asin terdeteksi pada titik $A, C, D$ dan $G$.
\end{abstract}

Kata Kunci: Airtanah Asin, Pesisir, Geolistrik, Kota Cilacap

\section{IDENTIFY THE SALINE GROUNDWATER BASED ON ESTIMATION OF GEOELECTRIC IN COASTAL OF CILACAP CITY CENTRAL JAVA}

\begin{abstract}
$\underline{\text { Abstract }}$
Groundwater is one of the potential water resources that can be used to meet the water needs of humans. Excessive utilization of groundwater in coastal areas often lead to seawater intrusion. This study aims to determine keterdapatan salty groundwater in the Coastal city of Cilacap. The analysis was done by estimating geoelectric. Data analysis was performed using software IP2Win. The analysis showed that the salty groundwater detected at points $A, C, D$ and $G$.
\end{abstract}

Keywords: Salty Groundwater, Coastal Area, Geoelectric, Cilacap City

\section{PENDAHULUAN}

Sumberdaya air merupakan kebutuhan yang vital bagi makhluk hidup (Sudarmadji dkk, 2012). Keberadaan air begitu penting bagi kehidupan sehingga banyak peradaban yang berkembang di Bumi berada di dekat sumber air. Sunjoto (2009) menyebutkan bahwa keberadaan air yang begitu penting nampak pada banyaknya prasati keairan yang ada di Indonesia seperti Prasati Tukmas, Prasasti Pananggaran, Prasasti Canggrang, Prasati Manukaya dan Prasasti Samirana.

Ketersediaan sumberdaya air di Bumi, khususnya air tawar berbeda-beda antara ruang dan waktu. Cahyadi dkk. (2011) menyebutkan bahwa permasalahan terkait pemenuhan sumberdaya air meliputi empat hal, yaitu; (1) kuantitas sumberdaya air, (2) kualitas sumberdaya air, (3) distribusi spasial sumberdaya air, dan (4) distribusi temporal 
sumberdaya air. Permasalahan-permasalahan tersebut di setiap tempat tidak sama, sehingga membutuhkan kajian mendalam terhadap masing-masing permasalahan.

Airtanah merupakan salah satu sumber air tawar yang dapat dimanfaatkan manusia (Purnama dan Sulaswono, 2006; Purnama dan Marfai, 2012). Keberadaannya di bumi merupakan jumlah air tawar yang paling banyak di bandingkan dengan sumber air tawar yang lain kecuali air tawar yang berbentuk es di kutub (Todd, 1980; Zohdy dkk, 1980). Hal ini yang menyebabkan airtanah memiliki peranan yang besar bagi pemenuhan kebutuhan air manusia di bumi.

Airtanah sangat banyak digunakan untuk memenuhi kebutuhan air manusia karena beberapa alasan, yakni memiliki kualitas yang relatif baik serta relatif lebih sulit untuk mengalami pencemaran dibandingkan dengan air permukaan. Namun demikian, airtanah di suatu wilayah memiliki batas aman tertentu untuk dapat dimanfaatkan. Pemanfaatan yang berlebihan (melebihi hasil aman suatu akuifer) dapat menyebabkan terjadinya kerusakan sumberdaya airtanah.

Airtanah di wilayah pesisir memiliki kerentanan terhadap pencemaran yang tinggi. Kondisi ini disebabkan oleh karena adanya kontak langsung dengan airlaut. Persinggungan antara airtanah tawar dan air asin disebut sebagai zona interface. Akibat adanya interface di dalam akuifer di wilayah pesisir, maka pemanfaatan yang berlebihan akan menyebabkan terjadinya intrusi airlaut, atau dapat pula terjadi akibat adanya jebakan air asin yang terbentuk karena sejarah pengendapan material di suatu lokasi (Purnama, 2005).

Intrusi air laut ke dalam sistem airtanah di wilayah pesisir merupakan persoalan yang serius (Purnama dan Marfai, 2012). Hal ini karena sumberdaya airtanah tidak akan lagi dapat dimanfaatkan lagi untuk memenuhi kebutuhan air bagi manusia karena kualitasnya yang tidak memenuhi syarat. Selain itu, airtanah yang mengalami intrusi air laut sulit untuk dipulihkan, atau pemulihannya membutuhkan waktu yang lama.

Penelitian Pesisir ini bertujuan untuk melakukan identifikasi airtanah asin di sebagian pesisir Kota Cilacap. Wilayah kajian mengalami perkembangan yang pesat mengingat banyaknya aktivitas industri dan pembangkit energi. Selain itu, perkembangan kota Cilacap yang ditandai dengan meningkatnya jumlah penduduk telah menyebabkan semakin banyaknya kebutuhan akan sumberdaya air khususnya airtanah semakin meningkat.

\section{Metode Penelitian}

Penyelidikan geolistrik yang menganalisis karakteristik akuifer berdasarkan tahanan jenis akan memberikan gambaran sifat batuan didasarkan atas nilai tahanan jenis dari arus listrik yang dihantarkan ke dalam bawah tanah. Perbedaan dan penyebaran tahanan jenis setiap lapisan batuan bawah permukaan baik secara vertikal maupun horisontal akan disajikan dalam bentuk penampang geologi yang didasarkan pada hasil pengukuran tahanan jenis di lokasi kajian (Gambar 1).

Lokasi kajian di wilayah pesisir Kota Cilacap, Provinsi Jawa Tengah. Pengukuran dilakukan pada sembilan titik yang membentuk tiga penampang melintang tegak lurus terhadap garis pantai. Berdasarkan hasil penelitian tersebut, maka diharapkan diperoleh sebaran airtanah asin pada tiga penampang yang tegak lurus terhadap garis pantai.

Prinsip dari penyelidikan geolistrik dilakukan dengan cara mengalirkan arus listrik searah ke dalam bumi melalui 2 (dua) arus elektroda arus C1 dan C2, dan akan terbentuk medan listrik yang komposisinya tergantung pada konfigurasi dan sifat listrik batuan yang ada dalam media di dalam tanah. Potensial yang ditimbulkan oleh arus ini diukur permukaan tanah dengan menggunakan 2 (dua) buah elektroda potensial tak terpolarisasikan (P1 dan P2) (Gambar 2). Apabila kuat arus yang dialirkan dan perbedaan 
potensial yang diukur diketahui, maka tahanan jenis lapisan batuan yang dilalui arus listrik akan dapat dihitung.
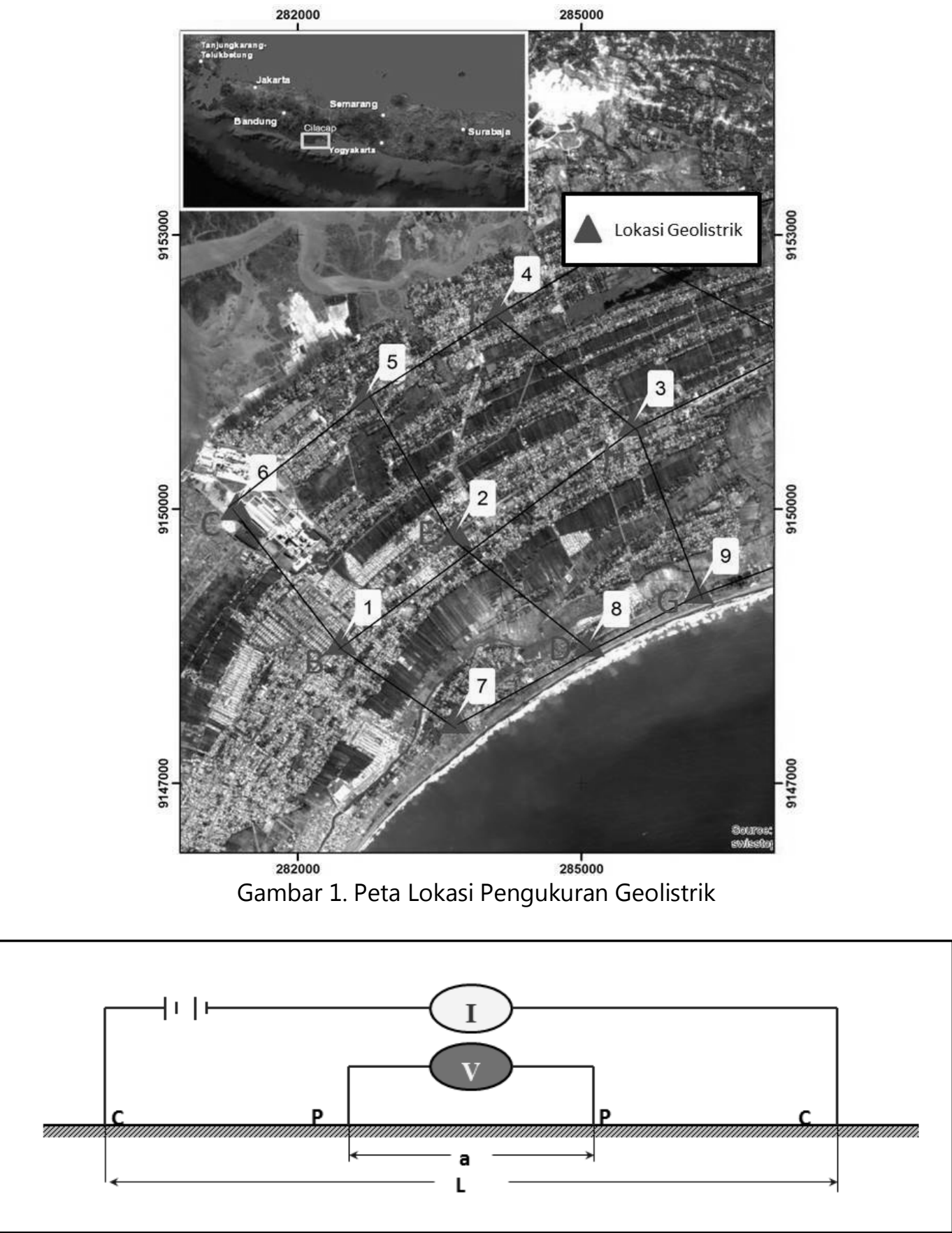

Gambar 2. Metoda Pengukuran Tahanan Jenis (Geolistrik)

Rangkaian Elektroda Metoda Konfigurasi Schlumberger dapat dijelaskan sebagai berikut:

$\begin{array}{rll}\mathrm{C} 1 ; \mathrm{C} 2 & = & \text { Elektroda Arus } \\ \mathrm{P} 1 ; \mathrm{P} 2 & = & \text { Elektroda Potensial } \\ \mathrm{V} & = & \text { Beda Potensial } \\ \mathrm{a} & = & \text { Jarak Elektroda Potensial } \\ \mathrm{L} & = & \text { Jarak Elektroda Arus }\end{array}$


Panjang rentang dalam penyelidikan ini sepanjang 200 meter. Dalam penyelidikan ini telah dipilih susunan elektroda menurut aturan konfigurasi Schlumberger. Disebabkan keadaan faktor geometris yang selalu berubah-ubah besarnya tahanan jenis semu $(\mathrm{Pa})$ dapat dihitung berdasarkan rumus sebagai berikut (Zohdy dkk, 1980):

(1)

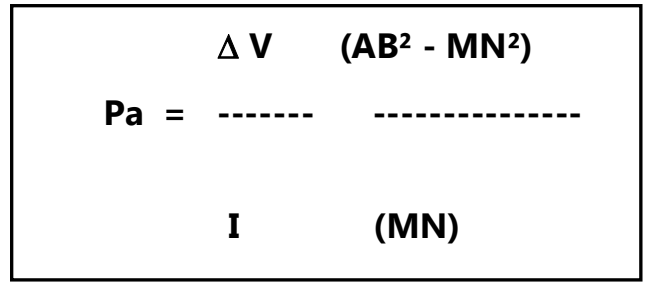

dimana :

$\mathrm{Pa}=$ tahanan jenis semu (Ohm $\mathrm{m})$

$\Delta \mathrm{V}=$ perbedaan tegangan yang diukur (volt)

$A B=$ jarak antara kedua elektroda arus $(m)$

$\mathrm{MN}=$ jarak antara elektroda potensial $(\mathrm{m})$

$\mathrm{I}=$ kuat arus yang dialirkan kedalam bumi (ampere)

Secara umum, prediksi kedalaman yang diperoleh dengan konfigurasi ini maksimum adalah $1 / 3$ dari jarak $A B$, seperti konfigurasi Wenner (Gambar 3) kedalaman ini adalah kedalaman maksimum yang diperoleh secara pendapat umum (rule of thumb) yang sering dipergunakan. Dalam konfigurasi schlumberger dikenal istilah eksentrisitas maksimum, yaitu nilai perbandingan antara jarak $M N / A B$, sehingga sesuai dengan analisis konfigurasi schlumberger yakni jarak $M N$ cukup kecil bila dibandingkan dengan $A B$ (Gambar 4). Eksentrisitas yang sering dipergunakan adalah $1 / 3$ (untuk daerah konduktif) atau $1 / 5$ (untuk daerah resistif).

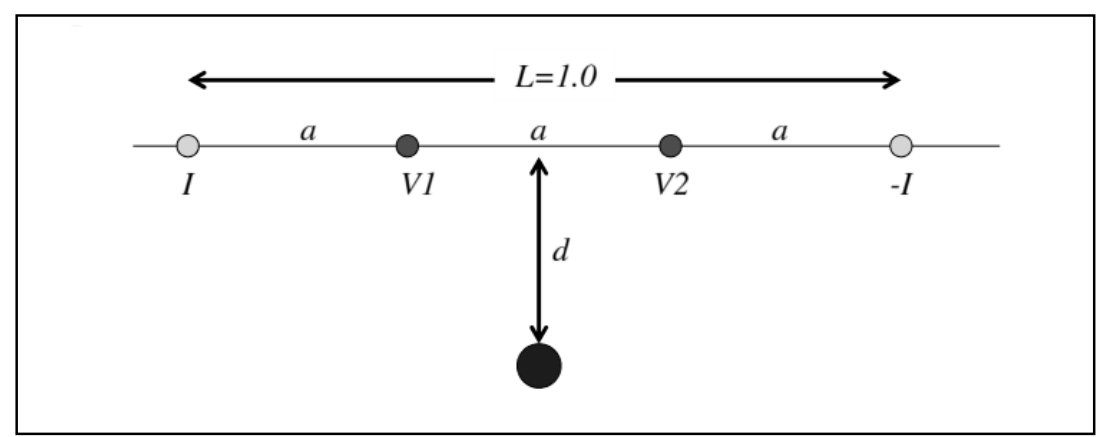

Gambar 3. Sketsa kedalaman konfigurasi Schlumberger 


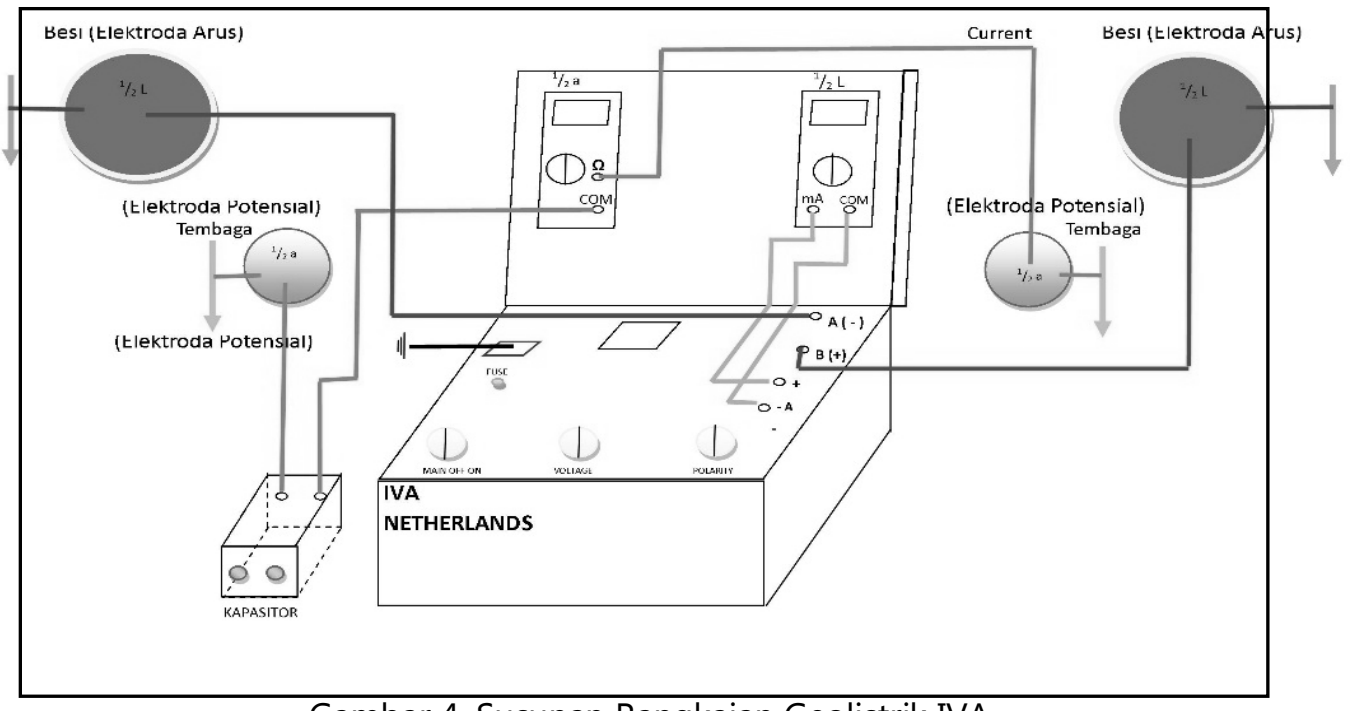

Gambar 4. Susunan Rangkaian Geolistrik IVA

Penafsiran data lapangan metoda tahanan jenis ini dilakukan dengan menghubungkan kondisi sifat fisik batuan. Dasar penafsiran adalah hubungan besaran nilai tahanan jenis dengan jenis batuan. Air asin atau alir laut memiliki nilai tahanan jenis yang lebih rendah jika dibandingkan dengan batuan yang mengandung air tawar. Faktor lain yang akan mempengaruhi nilai tahanan jenis adalah kandungan mineral, susunan litologi dan struktur geologi.

Teknik interpretasi data lapangan dilakukan dengan cara dihitung secara sistematis kemudian dapat diperkiraan nilai tahanan jenis batuan dari setiap material yang dilewati oleh aliran listrik (Tabel 1). Berdasarkan perhitungan tersebut, nilai tahanan jenis dan ketebalan masing-masing setiap lapisan di modelkan dengan bantuan Software IP2Win sehingga diperoleh hasil penafsiran yang lebih akurat dengan prosentasi kesalahan yang kecil disetiap jarak spasi dan posisi datum dari pengukuran geolistrik.

Tabel 1. Korelasi Tahanan jenis terhadap batuan

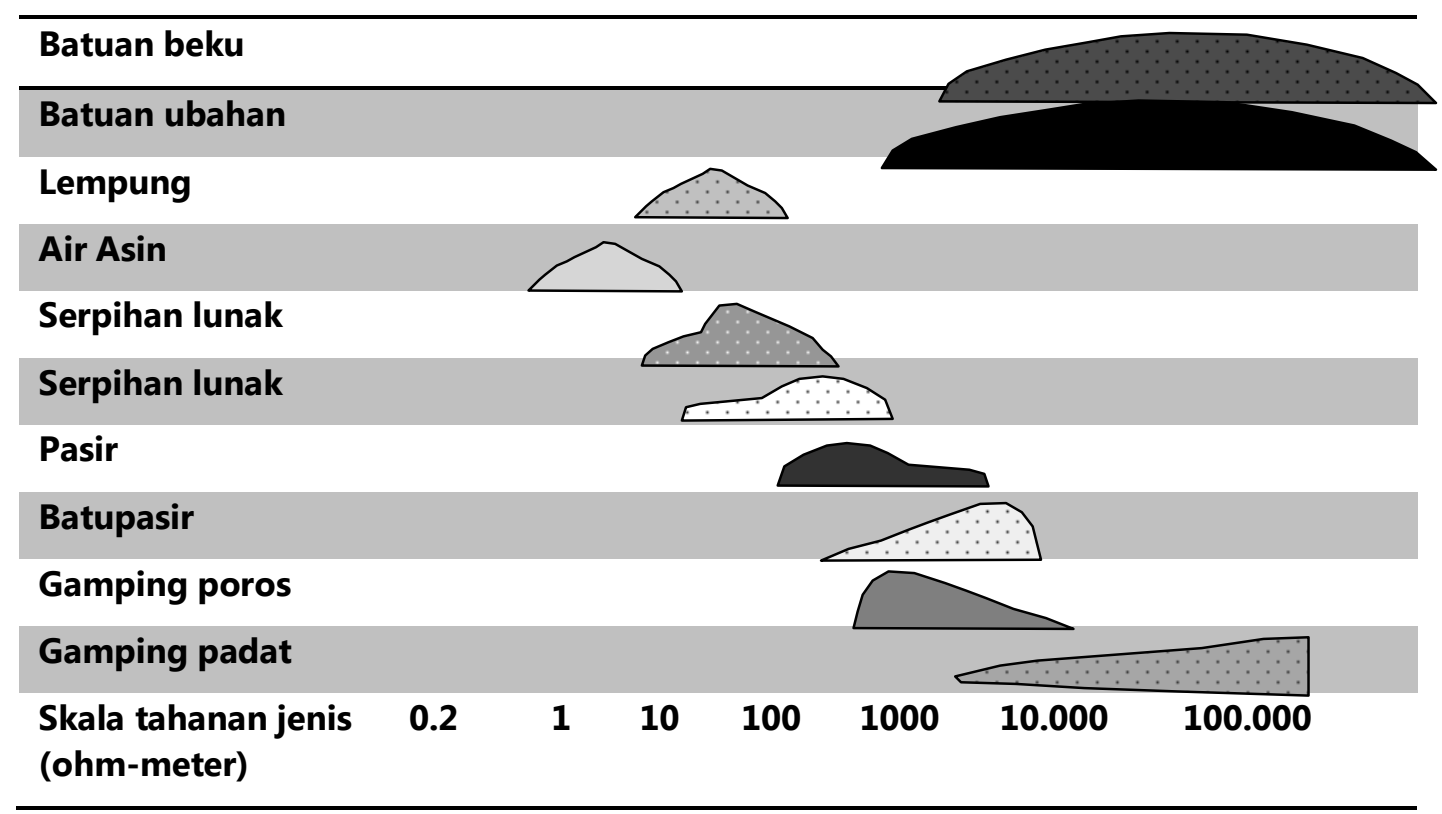

Sumber: Milson (2003) dengan modifikasi 
Hasil penafsiran titik pendugaan geolistrik dari nilai tahanan jenisnya kemudian dikorelasikan dengan pendugaan geolistrik di lokasi pendugaan yang lain, kemudian disajikan penampang litologi berdasarkan tahanan jenis yang dapat memberikan gambaran konfigurasi bawah permukaan yaitu hubungan litologi secara vertikal dan horizontal, kedalaman serta ketebalan, sehingga dapat memberikan informasi intrusi air laut. Intrusi air lau ditunjukan dengan nilai tahanan jenis $\leq 3 \Omega$ meter. Korelasi tahanan jenis dapat dilihat pada Tabel 1. Hasil pengukuran geolistrik diolah dengan menggunakan software IP2Win. Hasil analisis awalnya berupa nilai-nilai hambatan jenis pada kedalamankedalaman tertentu hasil pengukuran. Data kemudian diinterpretasi untuk menentukan keterdapatan airtanah asin di lokasi kajian.

\section{Hasil Penelitian dan Pembahasan Penampang A-B-C}

Hasil analisis terhadap penampang A-B-C menunjukkan bahwa airtanah asin terdeteksi di titik A dan C. Airtanah asin di titik A terdapat pada kedalaman 12 meter dari permukaan tanah, atau terdapat pada ketinggian -4 meter dari permukaan laut. Hal ini menunjukkan bahwa airtanah asin berasal dari laut. Berdasarkan pada penampang A-B-C pada Gambar 5, diketahui bahwa keterdapatan airtanah asin di Titik A terjadi akibat adanya penurapan yang banyak di Titik A yang merupakan wilayah padat penduduk. Kondisi berbeda terjadi di Titik C, di mana airtanah asin berasal dari sungai. Muara Sungai yang dekat dengan laut, serta memeliki kemiringan yang kecil memungkinkan adanya gerakan air laut mendesak ke arah darat, terutama saat terjadi gelombang pasang. Kondisi demikian diikuti dengan penurapan airtanah yang cukup besar di Titik $C$ yang mengakibatkan air asin masuk pada sungai masuk ke dalam airtanah.

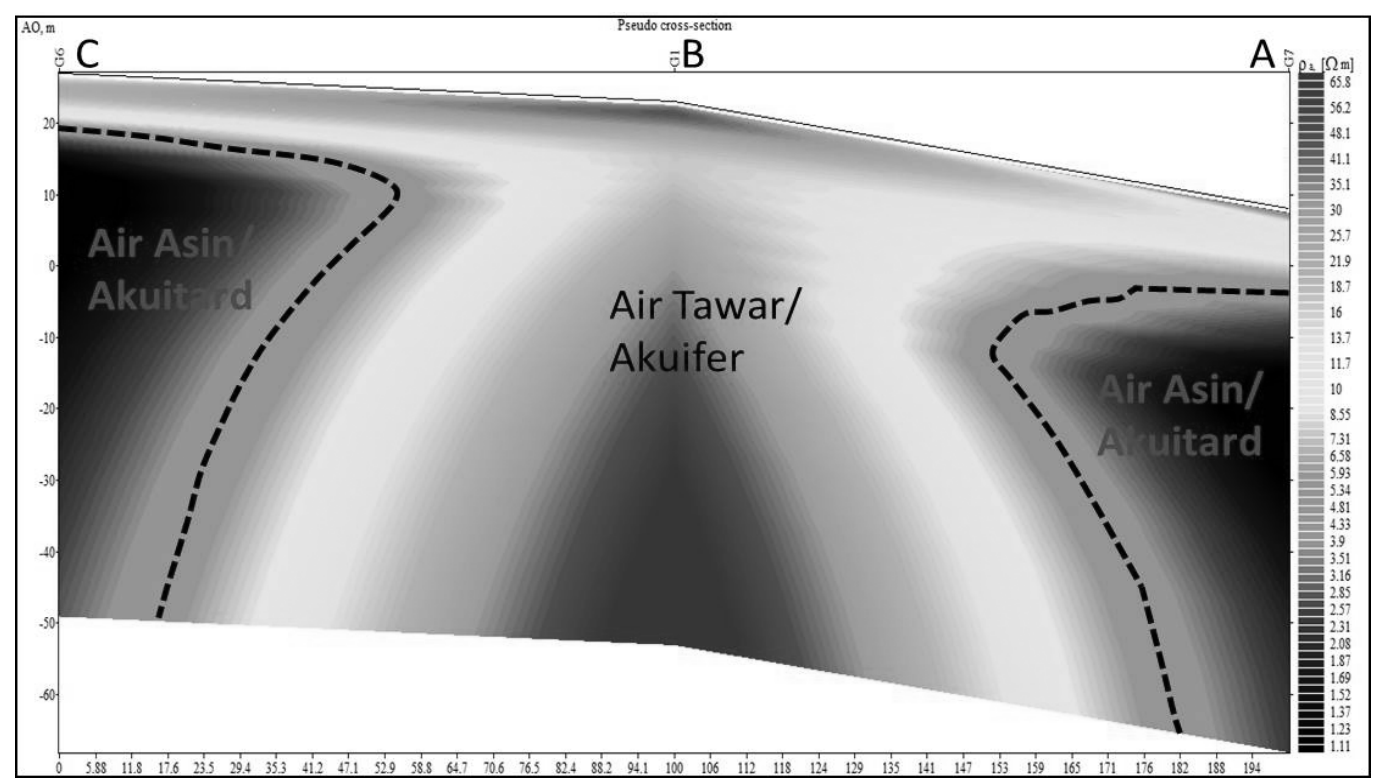

Gambar 5. Penampang Akuifer A-B-C

\section{Penampang D-E-F}

Hasil analisis pada penampang D-E-F diketahui bahwa airtanah asin hanya terdeteksi di Titik D (Gambar 6). Kondisi ini disebabkan karena Titik D terdapat di dekat pantai, sedangkan dua titik yang lain relatif lebih jauh dibandingkan dengan Titik D. Berdasarkan bertuk penampangnya, diketahui bahwa airtanah asin terbentuk akibat penurapan airtanah yang besar, dan dimungkinkan akan mengalami pergerakan semakin jauh ke arah Titik E. Berbeda dengan penampang A-B-C, pada pada penampang D-E-F 
titik terjauh tidak berdekatan dengan sungai, sehingga tidak terjadi intrusi air laut meskipun penurapan airtanah cukup besar.

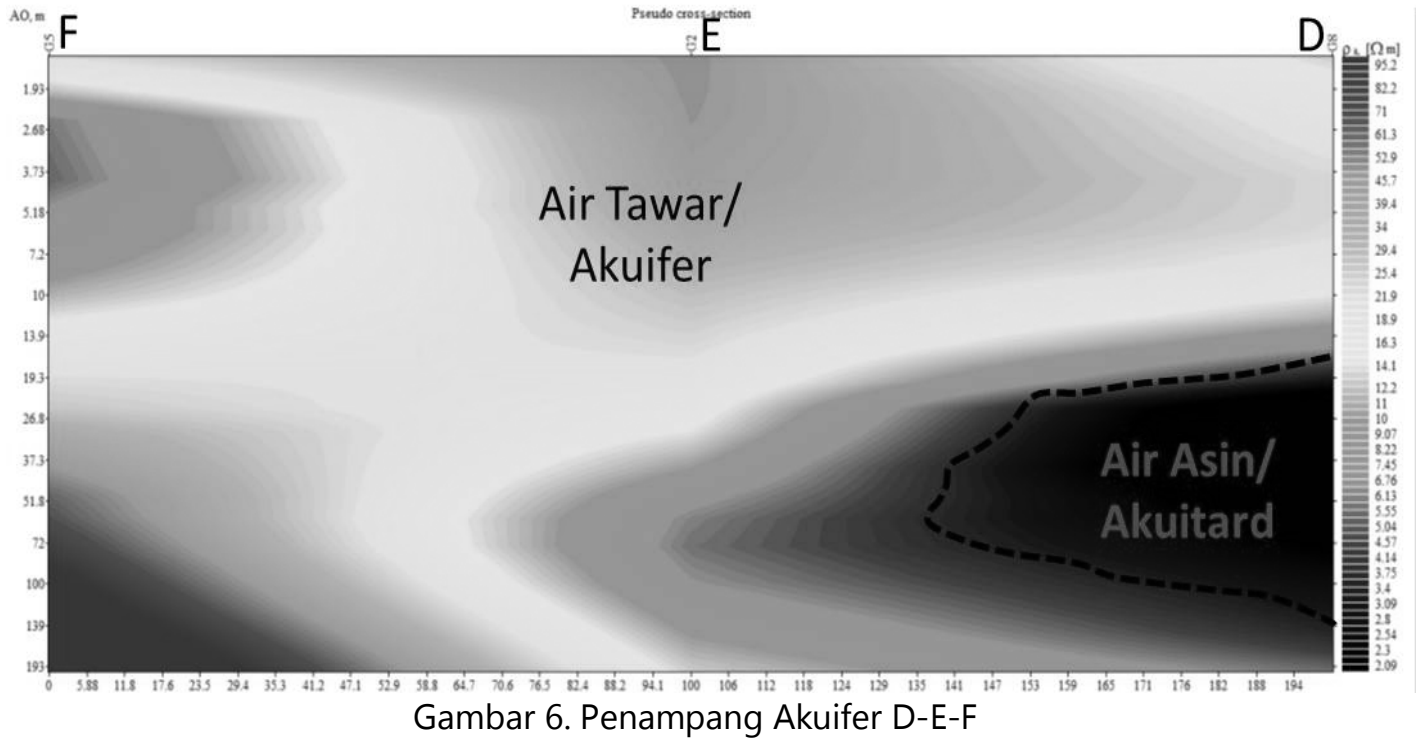

\section{Penampang G-H-I}

Hasil analisis pada penampang G-H-I diketahui bahwa airtanah asin hanya terdeteksi di Titik G (Gambar 7). Keterdapatan airtanah asin berdasarkan hasil rekonstruksi penampang G-H-I dengan menggunakan software IP2Win menunjukkan bahwa airtanah merupakan intrusi air laut yang disebabkan oleh penurapan airtanah yang berlebihan. Selain itu, diketahui bahwa terdapat kecenderungan arah intrusi air laut yang semakin jauh menuju ke arah Titik $\mathrm{H}$ (semakin jauh ke arah darat). Hasil analisis juga menunjukkan bahwa pada Titik $\mathrm{H}$ di bagian pemukaan memiliki nilai hambatan jenis yang rendah. Nilai ini tidak disebabkan oleh adanya airtanah asin, namun disebabkan oleh material lempung yang mendominasi lokasi tersebut. Hal ini dikuatkan dengan hasil pengamatan di lapangan terkait dengan material di lokasi kajian dan keterdapatan muka airtanah yang berada di kedalaman yang melebihi sebaran vertikal nilai hambatan jenis rendah pada titik tersebut.

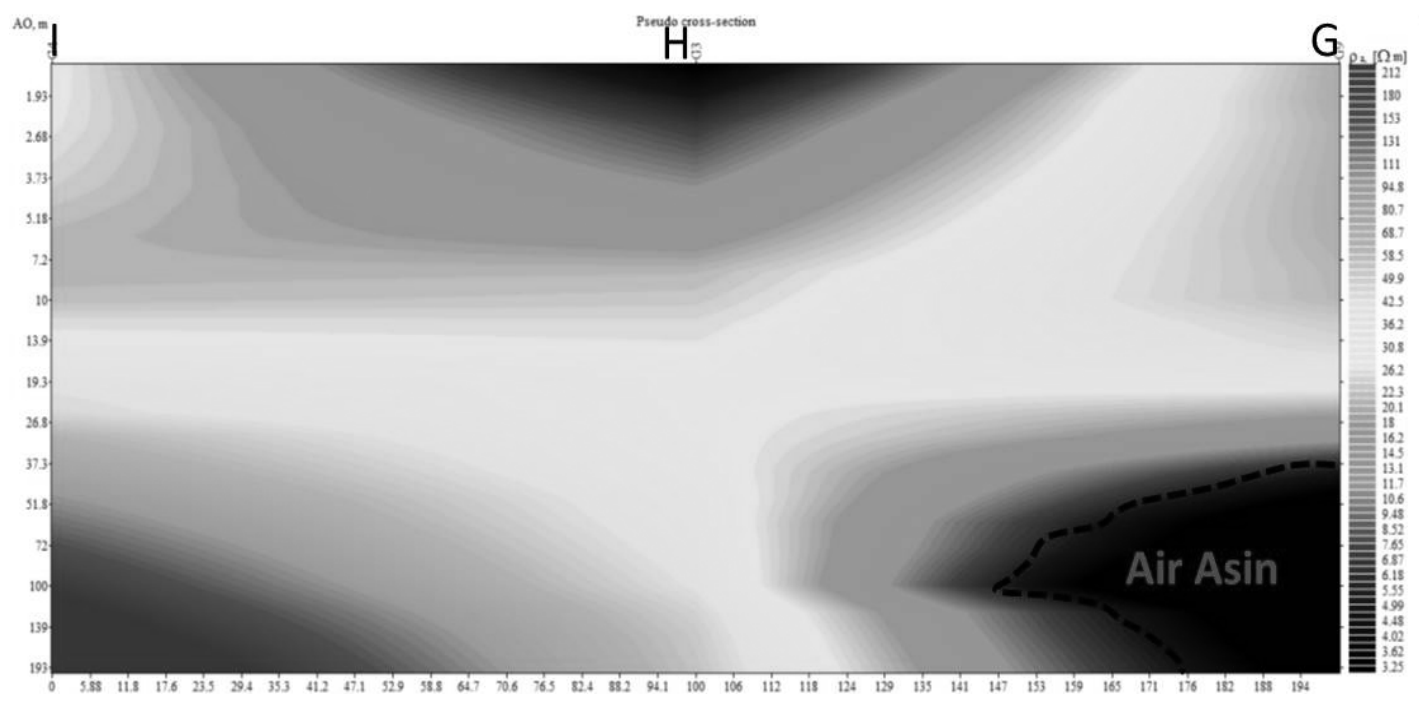

Gambar 7. Penampang Akuifer I-H-G 


\section{Kesimpulan}

Hasil analisis keterdapatan airtanah asin berdasarkan pendugaan geolistrik pada titik $A, B, C, D, E, F, G$ dan I menunjukkan bahwa keterdapatan airtanah asin nampak pada titik $A, C, D, H$ dan $G$. Airtanah asin terdeteksi pada titik $A$ di kedalaman 12 meter, titik $C$ di kedalaman 8 meter, titik $D$ di kedalaman 15 meter, dan titik $G$ diketemukan di kedalaman 37 meter. Keterdapatan airtanah asin di lokasi kajian disebabkan karena intrusi air laut yang terjadi akibat penurapan airtanah yang berlebihan. Gerakan airasin ke dalam airtanah di lokasi kajian melalui pantai dan sungai yang telah mengalami intrusi air laut melalui air permukaan.

\section{Pengakuan}

Penelitian ini merupakan bagian dari penelitian unggulan komprehensif yang berjudul "Kajian Kekritisan dan Konservasi Sumberdaya Airtanah Wilayah Pesisir Melalui Pemodelan dan Pengelolaan Intrusi". Penelitian ini dibiayai oleh DAFTAR ISIAN PELAKSANAAN ANGGARAN (DIPA) UGM T.A 2013 SESUAI SURAT TUGAS PELAKSANAAN PENELITIAN NOMOR: LPPM-UGM/896/LIT/2013 TANGGAL 18 JUNI 2013.

\section{DAFTAR PUSTAKA}

Cahyadi, A.; Priadmodjo, A. dan Yananto, A. 2011. Criticizing The Conventional Paradigm of Urban Drainage. Proceeding The $3^{\text {rd }}$ International Graduated Student Conference on Indonesia. Yogyakarta, 8-9 November 2011. Hal: 547-553.

Milson, J. 2003. Field Geophysics, The Geological Field Guide Series 3rd Edition. West Sussex: John Wiley and Sons Inc.

Purnama S and M.A. Marfai. 2012. Saline Water Intrusion Toward Groundwater : Issues And Its Control. Journal of Natural Resources and Development 2012. Vol. 02. Hal: 25-32.

Purnama, S dan Sulaswono, B. 2006. Pemanfaatan Teknik Geolistrik untuk Mendeteksi Persebaran Airtanah Asin pada Akuifer Bebas di Kota Surabaya. Majalah Geografi Indonesia Vol. 20 (1). Hal: 52-66.

Purnama, S. 2005. Distribusi Airtanah Asin di Dataran Pantai Kota Semarang dan Kesediaan Membayar Penduduk dalam Perbaikan Kondisi Sumber Air. Majalah Geografi Indonesia, Vol. 19 (1). Hal: 41-61.

Sudarmadji; Suprayogi, S. dan Setiadi. 2012. Konservasi Mata Air Berbasis Masyarakat di Kabupaten Gunungkidul. Yogyakarta: Penerbit Sekolah Pascasarjana Universitas Gadjah Mada.

Sunjoto. 2009. Konsep Hamemayu Hayuning Bawono dalam Pengelolaan Sumberdaya Air Berkelanjutan. Pidato Guru Besar Universitas Gadjah Mada Yogyakarta.

Todd, D.K. 1980. Groundwater Hydrology. New York: John Wiley and Sons Inc.

Zohdy, A.A.R.; Eaton, G.P. dan Mabey, D.R. 1980. Application of Surface Geophysics to Groundwater Investigation. Washington: United States Department of The Interior. 